\title{
NOTA
}

\section{RESPOSTAS DE DIFERENTES GENÓTIPOS DE BATATA À TUBERIZAÇÃO IN VITRO ${ }^{(1)}$}

\author{
BENEDITA MARIA RODRIGUES-OTUBO ${ }^{(2)}$, JOSÉ ALFREDO USBERTI FILHO ${ }^{(3,6)}$, \\ WALTER JOSÉ SIQUEIRA ${ }^{(3)}$, EDSON TOBIAS DOMINGUES ${ }^{(4)}$, \\ NEWTON PRADO GRANJA ${ }^{(5)} \&$ HILÁRIO DA SILVA MIRANDA FILHO(5)
}

\begin{abstract}
RESUMO
Avaliaram-se os desempenhos de seis genótipos de batata (Solanum tuberosum L.) quanto à produção de microtubérculos in vitro, a partir de segmentos apicais, empregando-se três diferentes meios de cultura e três épocas de avaliação (30, 60 e 90 dias). O meio de cultura BT2 contendo BAP $\left(5,0 \mathrm{mg} . \mathrm{L}^{-1}\right)$, sacarose (80 g.L $\left.\mathrm{L}^{-1}\right)$ e Cycocel (500 mg. $\left.\mathrm{L}^{-1}\right)$ mostrou os melhores resultados quanto ao número total e à frequência de microtubérculos médios $\mathrm{e}$ pequenos induzidos in vitro. O BT1, suplementado com Kin $\left(2,5 \mathrm{mg} . \mathrm{L}^{-1}\right)$ e sacarose $\left(60\right.$ g.L $\left.\mathrm{L}^{-1}\right)$, foi eficiente somente para o cultivar Santé na produção de microtubérculos grandes, enquanto o BT3 mostrou resultados intermediários para os cultivares em estudo. A avaliação aos 90 dias foi a que melhor refletiu o desempenho dos cultivares nos meios de cultura utilizados.
\end{abstract}

Termos de indexação: batata, Solanum tuberosum L., microtubérculos, tuberização in vitro, micropropagação.

(1) Trabalho apresentado no 1ํㅡㄹ Encontro de Biotecnologia Vegetal, realizado em Brasília (DF), em dezembro de 1993. Recebido para publicação em 18 de novembro de 1998 e aceito em 25 de maio de 1999.

(2) Empaer, Caixa Postal 472, 79114-000 Campo Grande (MS).

(3) Centro de Genética, Biologia Molecular e Fitoquímica, Instituto Agronômico (IAC), Caixa Postal 28, 13001-970 Campinas (SP).

(4) Centro de Citricultura "Sylvio Moreira", IAC, Caixa Postal 4, 13490-000 Cordeirópolis (SP).

(5) Centro de Horticultura, IAC.

(6) Com bolsa de produtividade em pesquisa do CNPq. 


\title{
ABSTRACT \\ RESPONSES OF POTATO GENOTYPES FOR IN VITRO TUBERISATION
}

\begin{abstract}
Six potato (Solanum tuberosum L.) genotypes were tested for in vitro microtuber yield, using three culture media and three evaluation periods (30,60 and 90 days). The best results as to overall number and frequency of medium and small microtubers induced in vitro have been achieved with culture medium BT2 with BAP $\left(5.0 \mathrm{mg} . \mathrm{L}^{-1}\right)$, sucrose $\left(80 \mathrm{~g} . \mathrm{L}^{-1}\right)$ and Cycocel (500 mg. $\left.\mathrm{L}^{-1}\right)$. On the other hand, BT1 medium with Kin (2.5 mg. $\left.\mathrm{L}^{-1}\right)$ and sucrose $(60$ g. $\left.\mathrm{L}^{-1}\right)$ has shown high efficiency in the induction of large microtubers for the cultivar Santé while BT3 revealed average results for all the cultivars. Final evaluation period was best at 90 days, allowing to determine, with good precision, the performance of the potato cultivars in the culture media used.
\end{abstract}

Index terms: potato, Solanum tuberosum L., microtubers, in vitro tuberisation, micropropagation.

$\mathrm{Na}$ batata, a micropropagação encontra-se bem estabelecida, podendo ser utilizada para obtenção de plantas com alta sanidade a partir de meristemas (Wang \& Hu, 1982; Schilde-Rentschler \& Schmiediche 1984; Boxus \& Druart, 1986), para multiplicação rápida e segura e manutenção de germoplasma com base em gemas e segmentos nodais (Hussey \& Stacey, 1981).

Um método alternativo de propagação rápida é a microtuberização (Dodds, 1988), a partir de plantas livres de patógenos, que visa, principalmente, à produção de batata semente e à distribuição de germoplasma (Wang \& Hu, 1982; Hussey \& Stacey, 1984; Tovar et al., 1985; Estrada et al., 1986). Essa técnica já foi estudada para grande número de genótipos de diferentes bases genéticas (Estrada et al., 1986). Os microtubérculos apresentam as vantagens de ocupar pouco espaço de armazenamento, dispensar a aclimatação e a mão-de-obra especializada e apresentar maior facilidade de intercâmbio.

A tuberização in vitro é considerada um processo complexo, por ser controlada por uma série de fatores que vêm sendo investigados, a saber: sacarose (Abbott \& Belcher, 1986; Teixeira \& Pinto, 1991), reguladores de crescimento (Teixeira \& Pinto, 1991; Harvey et al., 1991; Pelacho \& Mingo-Castel, 1991; Leclerc et al., 1994), fotoperíodo (Abbott \& Belcher, 1986; Ortiz-Montiel \& Lozoya-Saldana, 1987; Pelacho \& Mingo-Castel, 1991; Seabrock et al., 1993), temperatura (Nowak \& Colborne, 1989), luz (Slimmon et al., 1989; Nowak \& Asiedu, 1992) e componentes do meio de cultura (Teixeira \& Pinto, 1989).

Segundo Menzel (1980), os retardantes de crescimento estimulam a tuberização de plantas de batata quando em condições desfavoráveis, enquanto, em cultura de tecidos, o retardante Cycocel é utilizado para induzir a formação de microtubérculos, principalmente em genótipos recalcitrantes (Tovar et al., 1985; Rosell et al., 1987).

Neste trabalho avaliou-se o comportamento de seis genótipos de batata, quanto à tuberização in vitro, em três meios de cultura e sob dois regimes de luminosidade.

\section{Material e Métodos}

Utilizaram-se os genótipos Omega, Santé, Serrana, Bintje, MPI-49540-2 e 7XY-1 introduzidos in vitro do Centro Internacional de la Papa (CIP) - Peru, e mantidos in vitro no banco de germoplasma da exSeção de Raízes e Tubérculos do IAC.

Inicialmente os genótipos foram subcultivados em meio de Murashige \& Skoog (1962) mediante inoculação de segmentos nodais, contendo apenas um nó, e mantidos em fotoperíodo de 16/8 horas de luz/ escuro e temperatura de $26 \pm 2^{\circ} \mathrm{C}$, visando ampliar o número de hastes com estádio vegetativo semelhante. 
Aos 40 dias de subcultivo, segmentos apicais contendo 6-8 nós (explantes), foram excisados das hastes micropropagadas e inoculados em três meios de cultura previamente descritos, porém com algumas alterações:

BT1 - Sais de MS, tiamina (1,0 mg. $\left.\mathrm{L}^{-1}\right)$, piridoxina (2,5 mg. $\left.\mathrm{L}^{-1}\right)$, acido nicotínico $\left(1,85 \mathrm{mg} . \mathrm{L}^{-1}\right)$, inositol (100 mg. $\left.\mathrm{L}^{-1}\right)$, cinetina (Kin) a $2,5 \mathrm{mg} . \mathrm{L}^{-1}$, sacarose (60 g.L L $\left.^{-1}\right)$ e ágar (6 g.L L $\left.^{-1}\right)$ (Palmer \& Smith, 1969, modificado);

BT2 - Sais de MS, vitaminas de BT1, Cycocel (2-chloroethyl) - trimetrylammonium choride: (500 $\mathrm{mg} / \mathrm{L}$ ), 6-benzilaminopurina (BAP) a $5 \mathrm{mg} . \mathrm{L}^{-1}$, sacarose $\left(80\right.$ g.L L $\left.^{-1}\right)$ e ágar $\left(6\right.$ g.L.$\left.^{-1}\right)$ (Estrada et al., 1986, modificado);

BT3 - Sais de MS, exceto para $\mathrm{NH}_{4} \mathrm{NO}_{3}$ com $825 \mathrm{mg} . \mathrm{L}^{-1}$, vitaminas de BT1, exceto para tiamina (0,4 mg. $\left.\mathrm{L}^{-1}\right)$, glicina $\left(2 \mathrm{mg} . \mathrm{L}^{-1}\right)$ e demais componentes de BT2 (Estrada et al., 1986, modificado).

Após ajustar o pH para 5,8, distribuíram-se os meios em frascos de $100 \mathrm{~mL}$ e autoclavaram-nos a uma atmosfera de pressão e temperatura de $120^{\circ} \mathrm{C}$ por 20 minutos.

Instalaram-se dois experimentos, sendo o primeiro sob regime de 8 horas de luz (intensidade luminosa de $50 \mathrm{mmol} / \mathrm{m}^{2} / \mathrm{s}$, através de lâmpada fluorescente branca fria) e temperatura de $\pm 28^{\circ} \mathrm{C}$, e o segundo, em ausência de luz e temperatura de $\pm 20^{\circ} \mathrm{C}$. Utilizou-se o delineamento inteiramente casualizado no esquema fatorial (3 meios x 6 genótipos), com 10 repetições por tratamento e parcela constituída de um frasco contendo 8 explantes.

Aos 30, 60 e 90 dias, avaliaram-se o número médio de microtubérculos por tratamento e, aos 90 dias, o tamanho de microtubérculos em três classes: pequeno $(\leq 30 \mathrm{mg}$ ); médio (> $30 \mathrm{mg}$ a $60 \mathrm{mg}$ ) e grande $(>60 \mathrm{mg})$.

Os dados de número médio de microtubérculos por tratamento foram analisados estatisticamente após transformação de $\sqrt{\mathrm{x}+0,5}$ sendo as médias comparadas pelo teste de Duncan, enquanto os dados de tamanho foram transformados em porcentagens, em relação ao número total de microtubérculos de todo o experimento.

\section{Resultados e Discussão}

No experimento, realizado em ausência de luz, não ocorreu a formação de microtubérculos em nenhum dos genótipos, ao contrário dos resultados de Ortiz-Montiel \& Lozoya-Saldanã (1987) (cultivares Atzimba e Juanita) e Nowak \& Asiedu (1992), os quais relataram menor tuberização in vitro no escuro, embora alguns cultivares tenham apresentado bom desempenho naquelas condições. Por outro lado, Pelacho \& Mingo-Castel (1991) demonstraram que, no escuro, a tuberização in vitro depende fortemente da presença de citocininas. Assim, percebe-se a ocorrência de significativa interação dos genótipos com a presença de fitorreguladores e presença/ausência de luz para a tuberização in vitro.

Quanto aos resultados em presença de luz, a combinação de BAP (5,0 mg.L $\left.\mathrm{L}^{-1}\right)$, com Cycocel $(500$ mg. $\left.\mathrm{L}^{-1}\right)$, associada à sacarose $\left(80 \mathrm{~g} . \mathrm{L}^{-1}\right)$ no meio BT2, promoveu a maior produção média de microtubérculos (M5 = 5,42), desconsiderando o cultivar e o período de avaliação, sendo significativamente superior às observadas em meio BT3 $(\mathrm{M} 6=4,54)$ modificado pela redução do nitrato de amônia e da tiamina, e em BT1 contendo apenas Kin a 2,5 mg.L $\mathrm{L}^{-1}$ e sacarose a 60 g.L.-1 (M4 = 4,08) (Quadro 1).

O comportamento médio da produtividade, no decorrer das avaliações, diferiu dentro dos meios estudados. Apenas o BT1 mostrou maior produção média aos 90 dias $(5,04)$, enquanto, nos demais, o período de 60 dias não diferiu significativamente do de 90 , embora a produção média observada aos 90 dias seja levemente superior, tendo o BT2 alcançado 6,36 microtubérculos e o BT3 5,38 microtubérculos por tratamento. Slimmon et al. (1989) também relataram bons resultados de tuberização in vitro, aos 84 dias. Segundo Leclerc et al. (1994), a produção de microtubérculos obtida aos 28 dias de incubação não diferiu significativamente da de 56 dias, para os cultivares em estudo. 
Quadro 1. Número médio de tubérculos por tratamento, resultantes da inoculação de seis genótipos de batata (Solanum tuberosum L.), em três meios de tuberização (BT1, BT2 e BT3 - vide texto), avaliados aos 30, 60 e 90 dias de cultura

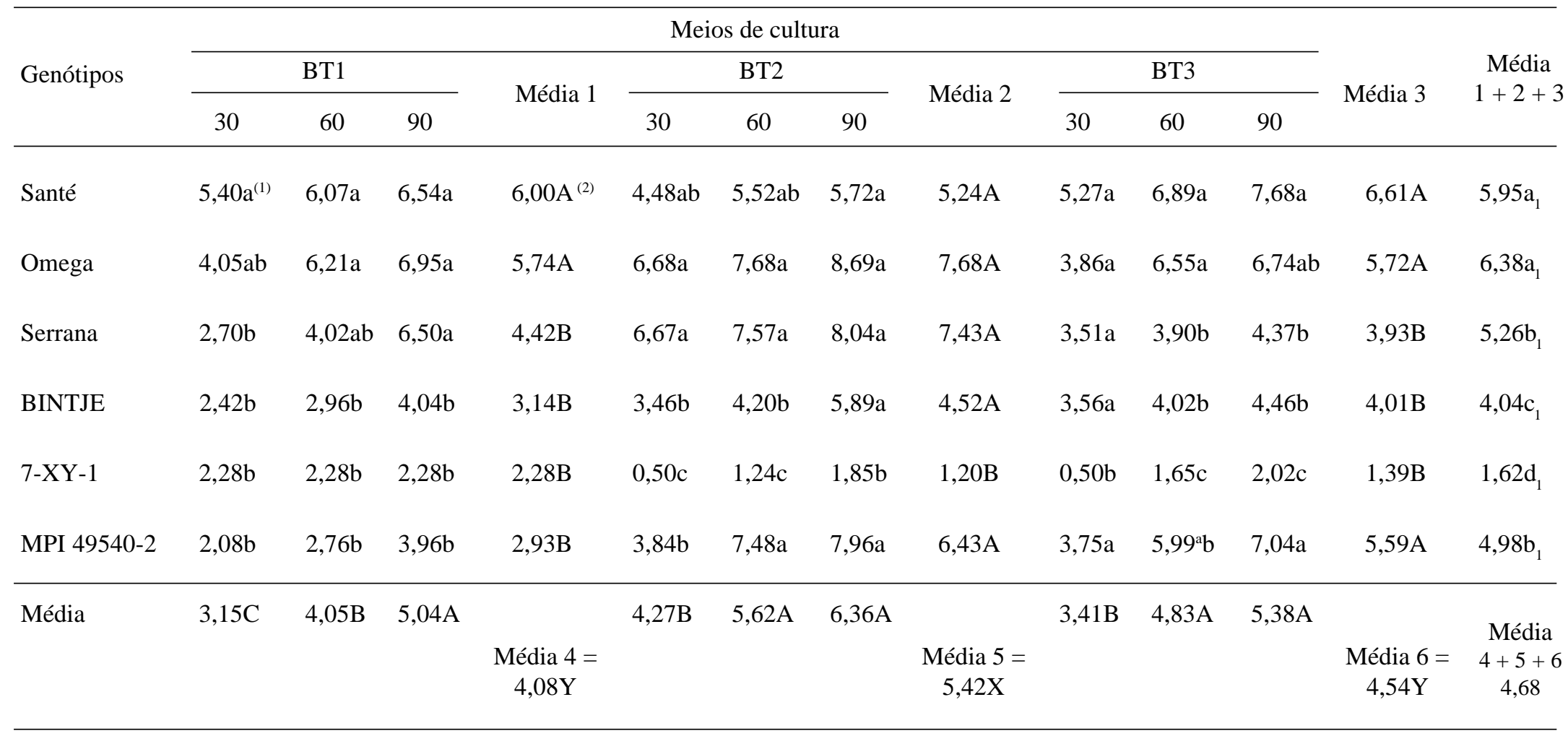

(1) Médias na mesma coluna, seguidas de diferentes letras minúsculas, com e sem subscritos, são estatisticamente diferentes entre si, de acordo com o teste de Duncan, a $5 \%$ de probabilidade.

(2) Médias na mesma linha, seguidas de diferentes letras maiúsculas, são estatisticamente diferentes entre si, segundo o teste de Duncan, a $5 \%$ de probabilidade. 
Acentuado acréscimo da produção de microtubérculos ocorreu no 'Serrana' de 60 para 90 dias, no meio BT1, equiparando-se aos cultivares Omega e Santé (Quadro 1). A produtividade deste genótipo aos 90 dias foi, praticamente, semelhante à observada aos 30 dias, em meio BT2. Tendência semelhante também se verificou para Omega em relação ao meio BT2, aos 30 dias, e ao BT3 aos 90, indicando que a resposta do genótipo está associada à eficiência do meio de cultura e ao período de incubação. Pelos resultados, sugere-se o período de 90 dias para avaliar o número total de microtubérculos.

Em relação aos genótipos em teste, considerando-se as médias das três avaliações, o cultivar Santé se mostrou o mais produtivo no meio BT1 $(6,00$ microtubérculos), enquanto no BT3 os genótipos Santé, Omega e MPI-49540-2 apresentaram as maiores produções de microtubérculos in vitro. A maioria dos materiais apresentou maior produção média no meio BT2, exceto 7XY-1, que se mostrou estatisticamente inferior aos demais (1,20 microtubérculo). Esse genótipo apresentou comportamento semelhante nos três meios de cultura estudados.

Provavelmente, o melhor desempenho dos genótipos no meio BT2 se devesse à presença de citocinina (BAP) associada à alta dose de sacarose e de Cycocel, conhecido inibidor de giberelina, que, segundo Pelacho \& Mingo-Castel (1991) e Chandra et al. (1992), provoca acentuada inibição da tuberização in vitro.

A redução da concentração de nitrato de amônia e de tiamina, mesmo associada à presença de cycocel, no meio BT3, afetou significamente o desempenho de Bintje e Serrana, aos 90 dias de cultivo. Esses resultados discordam de Teixeira \& Pinto (1991), que constataram aumento na produtividade de microtubérculos do cultivar Bintje em baixas doses de nitrogênio, porém na ausência de cycocel. A presença de cycocel nos meios em estudo favoreceu somente o desempenho do genótipo MPI 49540-2.

A presença de Kin a 2,5 mg. $\mathrm{L}^{-1}$ e de sacarose a 60 g.L $\mathrm{L}^{-1}$ no BT1 tornou-o menos eficiente em relação ao BT2, exceto para os genótipos Santé e Omega, que se sobressaíram com maior produtividade. OrtizMontiel \& Lozoya-Saldana (1987) constataram que o meio suplementado com Kin a $2,5 \mathrm{mg} . \mathrm{L}^{-1}$ promoveu maior tuberização in vitro em relação ao suplementado com BA (10 mg. $\left.\mathrm{L}^{-1}\right)$ e alta sacarose, tanto em ausência quanto em presença de luz (fotoperíodo de 8 horas), enquanto, neste trabalho os melhores resultados foram obtidos em meio contendo $5 \mathrm{mg} . \mathrm{L}^{-1}$ de BAP, alta sacarose e cycocel. Leclerc et al. (1994), comparando meios contendo BA-CCC e alta dose de sacarose $\mathrm{x}$ alta sacarose, constataram que o efeito do BA foi mascarado em alta sacarose, concordando com Teixeira \& Pinto (1991), enquanto outros autores verificaram o efeito do BA mesmo em concentrações elevadas de sacarose (Wang et al., 1982; Abbott \& Belcher, 1986).

Em termos gerais, apresentaram melhor desempenho os genótipos Santé e Omega, enquanto o 7XY-1 foi o menos responsivo, para os três meios testados, mostrando-se o BT2 mais eficiente para a maioria dos materiais estudados.

Na Figura 1, pode-se observar o desempenho dos genótipos, nos três meios de cultura, quanto às freqüências de microtubérculos obtidas nas três classes de tamanho (pequeno, médio e grande). Quanto à produção de microtubérculos grandes, o cultivar Santé destacou-se dos demais, principalmente no meio BT1, em vista, provavelmente, do seu excelente desempenho na presença de Kin. Nas classes de tamanho médio e pequeno, os demais cultivares tiveram baixo desempenho. Esse resultado demonstra que o tamanho está relacionado com a interação de vários fatores, como o meio, o genótipo, a presença de luz, etc. Resultados de Slimmon et al. (1989) e Novak \& Asiedu (1992) mostraram que a maior produção de microtubérculos grandes ocorreu na presença de luz.

No meio BT2, a maioria dos cultivares apresentou boa resposta à indução de microtubérculos pequeno e médio, com destaque para o 'Omega', nas três classes de tamanho.

O meio BT3 mostrou-se intermediário quanto à produção de microtubérculos, com destaque para MPI-49540-2 e Santé, com microtubérculos pequenos. 


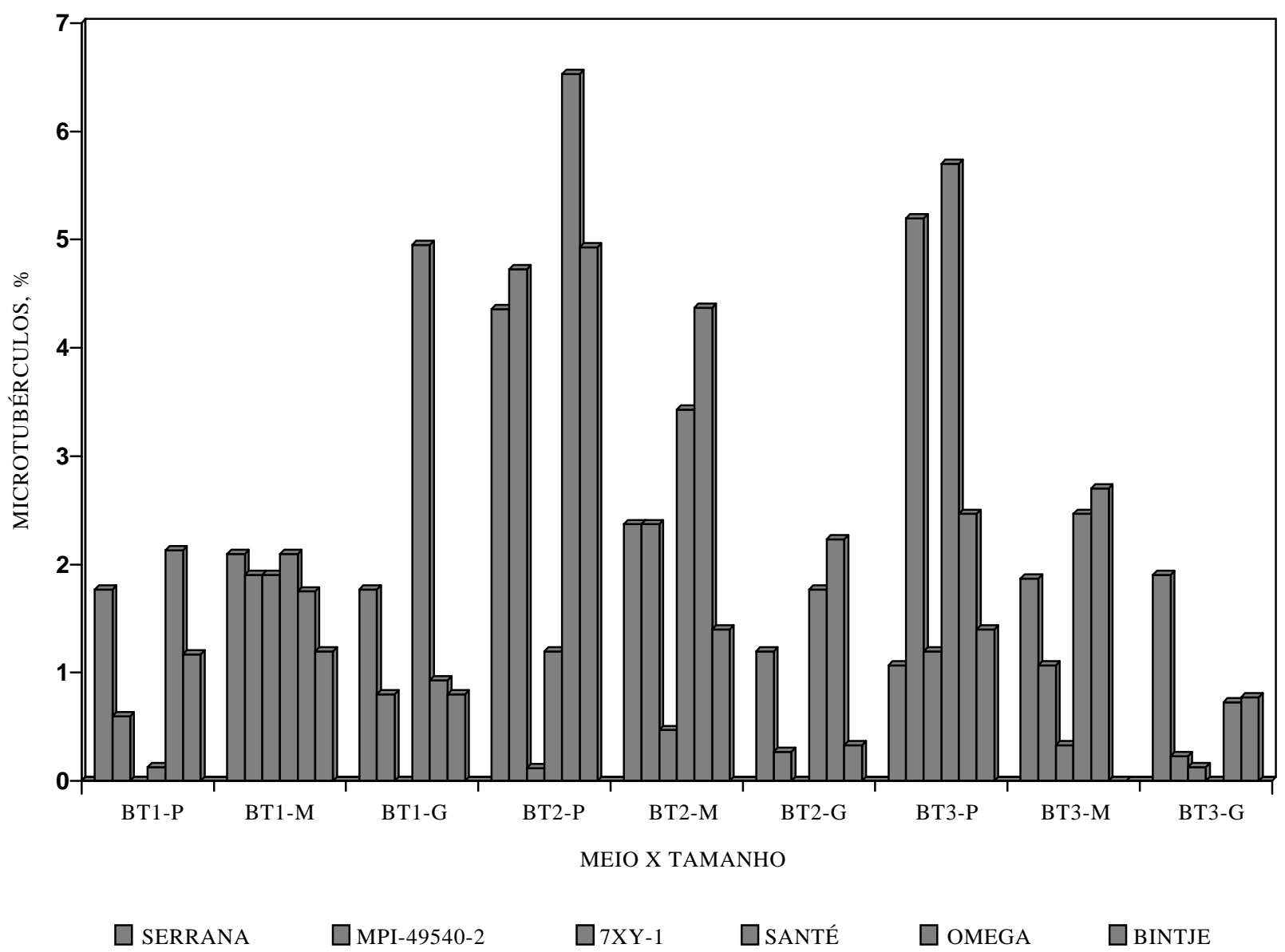

Figura 1. Freqüências observadas de microtubérculos de três tamanhos: $\mathrm{P}(\geq 30 \mathrm{mg})$; M (> 30 a 60$)$ e $\mathrm{G}(<60 \mathrm{mg})$, produzidos in vitro, em seis genótipos de batata inoculados em três meios de cultura (BT1, BT2 e BT3 - vide texto), avaliados aos 90 dias.

Em resumo, ocorreu acentuada interação cultivar x meio de cultura quanto à produção de microtubérculos de diferentes tamanhos. Sugere-se, portanto, o meio de cultura mais genérico: o BT2. Para os genótipos que mostraram resposta baixa ou nula, justifica-se testar novos meios de tuberização in vitro ou a alternativa de transplantar direto as plantas micropropagadas: sua grande vantagem é que plantas livres de doenças produzem microtubérculos de melhor qualidade, resultando, pois, em alta produtividade (Estrada et al., 1986).
Ocorreu microtuberização somente na presença de luz para todos os genótipos. O meio BT2 foi considerado o melhor para a maioria deles: aos 90 dias de cultivo, sobressaíram os tubérculos de tamanhos pequeno e médio.

\section{Agradecimentos}

Ao CNPq, pelas bolsas e auxílios e, em especial, à Técnica de Laboratório Rauly Máximo Rabelo Moreti, pelo apoio. 


\section{Referências Bibliográficas}

ABBOTT, A.J. \& BELCHER, A.R. Potato tuber formation in vitro. In: WITHERS, L.A. \& ALDERSON, P.G.,eds. Plant Tissue Culture and its Agricultural Applications. London, Butterwoths, 1986. p.113-122.

BOXUS, P.H. \& DRUART, P.H. Virus-free trees through tissue culture. In: BAJAJ, Y.P.S., ed. Biotechnology in Agriculture and Forestry, Trees I. Berlin, SpringerVerlag, 1986. v.1, p.24-30.

CHANDRA, R.; RANDHAWA, G.J.; CHAUDHART, D.R. \& UPADHYA, M.O. Efficacy of triazoles for in vitro microtuber production in potato. Potato Research, Wageningen, 35:339-341, 1992.

DODDS, J.H. Tissue culture technology: practical application of sophstycated methods. American Potato Journal, Orono, 65(4):167-180, 1988.

ESTRADA, R,P.; TOVAR, P. \& DODDS, J.H. Induction of in vitro tubers in a broad range of potato genotypes. Plant Cell Tissue and Organ Culture, Dordrecht, 7:3-10, 1986.

HARVEY, B.M.R. CROTHERS, S.H.; EVANS, N.E. \& SELBY, C. The use of growth retardants to improve microtuber formation by potato (Solanum tuberosum). Plant Cell Tissue and Organ Culture, Dordrecht, 27:5964, 1991.

HUSSEY, G. \& STACEY, N.J. In vitro propagation of potato (Solanum tuberosum L.). Annals of Botany, London, 40:787-796, 1981.

HUSSEY, G. \& STACEY, N.J. Factors affecting the formation of in vitro tubers of potato. Annals of Botany, London, 53:565-578, 1984.

LECLERC, Y., DONNELLY, D.J. \& SEABROOK, J.E.A . Microtuberisation of layered shoots and nodal cuttings of potato: the influence of growth regulators and incubation periods. Plant Cell, Tissue and Culture, Dordrecht , 37:113-120, 1994.

MENZEL, C.M. Tuberisation of potato at high temperatures: responses to gibberellin and growth inhibitors. Annals of Botany, London, 46:259-265, 1980.
MURASHIGE, T. \& SKOOG, F. A revised medium for rapid growth and bioassays with tobacco tissue cultures. Physiologia Plantarum, Copenhagen, 5:473-397, 1962.

NOWAK, J. \& ASIEDU, S.K. Gelling agent and light effects on in vitro tuberisation of potato cultivars. American. Potato Journal, Orono, 69:461-470, 1992.

NOWAK, J. \& COLBORNE, D. In vitro tuberisation and tuber proteins as indicators of heat stress tolerance in potato. American Potato Journal, Orono, 66:35-45, 1989.

ORTIZ-MONTIEL, G. \& LOZOYA-SALDANA, H. Potato minitubers: Technology validation in Mexico. American. Potato Journal, Orono, 64:535-544, 1987.

PALMER, C.E. \& SMITH, O.E. Cytokinins and tuber initiation in the potato Solanum tuberosum L. Nature, 221:279280, 1969.

PELACHO, A.M. \& MINGO-CASTEL, A.M. Effects of photoperiod on kinetin-induced tuberisation of isolated potato stolons cultured in vitro. American Potato Journal, Orono, 68:533-541, 1991.

ROSSELL, G.; BERTOLDI, F.D. de \& TÍZIO, R. In vitro mass tuberisation as a contribution to potato micropropagation. Potato Research, Netherlands, 30:111116, 1987.

SEABROOK, J.E.A. SHIRLYN, C. \& LEVY, D. Effect of photoperiod on in vitro tuberisation of potato (Solanum tuberosum L.). Plant Cell, Tissue and Organ Culture, Dordrecht, 34:43-51, 1993.

SCHILDE-RENTSCHLER, L. \& SCHMIEDICHE, P.E. Tissue culture: past, present and future. Circular CIP, Lima, 12(1):1-6, 1984.

SLIMMON, T.; MACHADO, V.S. \& COFFIN, R. The effect of light on in vitro microtuberisation of potato cultivars. American Potato Jurnal, Orono, 66:843-848, 1989.

TEIXEIRA, D.M.C. \& PINTO, J.E.B.P. Minituberização da batata em diferentes níveis de N, Sacarose e BAP. Revista Brasileira de Fisiologia Vegetal, 3(2):77-81, 1991.

TOVAR, P.; ESTRADA, R., SCHILDE-REENTSCHLER, L. \& DODDS, J.H. Induction y utilization de tuberculos in vitro de papa. Circular CIP, Lima, 13(4):1-5, 1985.

WANG, P. \& HU, C. In vitro mass tuberisation and virus free seed potato production in Taiwan. American Potato Journal, Orono, 59:33-37, 1982. 